\title{
El ecosistema digital: un corpus de estudio del español [presentación del monográfico]
}

\section{The digital ecosystem: a corpus study of the Spanish language [monograph presentation]}

\section{Coordinadoras científicos / Scientific coordinators}

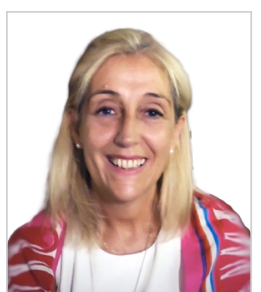

Pilar Fernández Martínez. Doctora en Lingüística Hispánica por la Universidad Complutense de Madrid. Profesora Titular en Lengua Española, del Departamento de Periodismo de la Universidad CEU San Pablo (Madrid). Desde 1987 a 1993 fue profesora en las licenciaturas en Ciencias de la Información y en Filología Hispánica, así como en la carrera de Magisterio en la Escuela Universitaria de Magisterio Fomento de Centros de Enseñanza (UCM). Comenzó su carrera investigadora con el profesor y académico Manuel Alvar. Es autora de más de cincuenta publicaciones sobre Gramática Normativa, Lengua y Medios de Comunicación, y sobre Lexicografía, y ha participado en diferentes congresos nacionales e internacionales, así como en distintos proyectos de investigación en el Plan Nacional de I+D+i. Profesora en grado, máster y doctorado. Ha sido Secretaria Académica de la Facultad de Humanidades y Ciencias de la Comunicación de la Universidad CEU San Pablo, así como directora de los Departamentos de Periodismo y de Filología de dicha facultad.

PhD in Hispanic Linguistics from the Universidad Complutense de Madrid. Full Professor in Spanish Language, Department of Journalism, CEU San Pablo University (Madrid). From 1987 to 1993 she taught in the Information Sciences and Hispanic Philology degrees, as well as in the Teaching degree at the Escuela Universitaria de Magisterio Fomento de Centros de Enseñanza (UCM. She began her research activity with professor and academic Manuel Alvar. Professor Fernández Martinez is the author of over fifty publications on Normative Grammar, Language and the Media, and on Lexicography, and has been a speaker at various national and international conferences, as well as participating in various research projects in the National R\&D\&I Plan). Lecturer for Bachelor, Master and Doctorate degrees. She has been the Academic Secretary of the Faculty of Humanities and Communication Sciences of the CEU San Pablo University, as well as director of the Departments of Journalism and Philology of that faculty.

Universidad CEU San Pablo, Madrid, España

pfernan@ceu.es

ORCID: 0000-0002-7436-0573

\section{Palabras clave:}

Español; internet; norma; relación lenguaje-realidad.

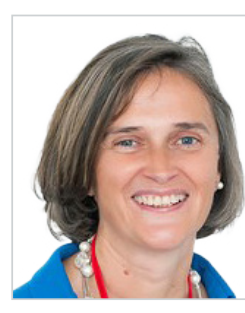

Ma Concepción Maldonado González. Doctora en Lingüística Hispánica por la Universidad Complutense de Madrid. En la actualidad, trabaja como profesora titular de Lengua Española en la Facultad de Ciencias de la Información de la Universidad Complutense de Madrid. Antes, desarrolló su labor docente e investigadora en la Universidad San Pablo-CEU. Desde 1987 hasta 2018 compaginó su actividad universitaria con su trabajo como responsable editorial en el grupo internacional SM, donde creó y dirigió el departamento de Lexicografía. Es autora del proyecto editorial de más de cien obras de referencia lingüística en distintos idiomas, y ha dirigido diccionarios, gramáticas, ortografías y manuales de enseñanza de segundas lenguas, publicados en España, Brasil, México, Colombia, Chile, Argentina, Puerto Rico, Perú y República Dominicana. Entre sus obras más destacadas cabe señalar sus trabajos sobre el discurso directo y el discurso indirecto, sus investigaciones lexicográficas, y, desde su creación en 2018, su tarea de divulgación lingüística en la revista Archiletras.

PhD in Hispanic Linguistics from the Universidad Complutense de Madrid. She currently works as a lecturer of Spanish Language in the Faculty of Information Sciences of the Complutense University of Madrid. Previously, she carried out her teaching and research work at CEU San Pablo University. From 1987 to 2018 she combined her university activity with her work as an editorial manager at the international group SM, where she founded and directed the department of Lexicography. She is the author of the editorial project of more than one hundred linguistic reference works in different languages, and has been in charge of dictionaries, grammars, orthographies and second language teaching manuals, published in Spain, Brazil, Mexico, Colombia, Chile, Argentina, Puerto Rico, Peru and the Dominican Republic. Some of her most outstanding achievements include her work on direct and indirect discourse, her lexicographical research, and, since her creation in 2018, her work on the dissemination of language in the journal Archiletras.

Universidad Complutense de Madrid, España

mariaconcepcionmaldonado@pdi.ucm.es

ORCID: 0000-0001-8921-2314

\section{Keywords:}

Spanish; internet; standard; relationship language-reality.

Cómo citar este artículo / How to cite this article:

Fernández Martínez, P; Maldonado González, Ma . C. (2020). El ecosistema digital: un corpus de estudio del español [presentación del monográfico]. Doxa Comunicación, 31, pp. 241-249. 


\section{Presentación}

Según datos obtenidos de la edición 2020 del Anuario del Instituto Cervantes (Instituto Cervantes, 2020: 5), casi 489 millones de personas tienen el español como lengua materna, lo que la convierte en la segunda lengua materna del mundo por número de hablantes, tras el chino mandarín. $\mathrm{Si}$, además de estos hablantes nativos, tenemos en cuenta el cómputo global de hablantes (que incluye también los de competencia limitada y los estudiantes de español como lengua extranjera), entonces el español se sitúa como la tercera lengua en el mundo, solo después del inglés y del chino mandarín.

Estos hablantes de español están presentes en cualquier parte del mundo. De hecho, se calcula que, en 2060, un 27,5\% de la población de Estados Unidos será de origen hispano, y este país será el segundo país hispanohablante, después de México. Es por ello por lo que, en la actualidad, a punto ya de alcanzar el primer cuarto del siglo XXI, el estudio de la lengua española cada vez va teniendo más en cuenta los medios digitales como espacios masivos de comunicación en español. En el ecosistema digital, en el que cada segundo se calcula que se realizan ya en torno a cinco millones de consultas (Lewis, 2020), estos hablantes de español se acercan cada día a distintas páginas web, a las aplicaciones de teléfonos móviles o a diferentes redes sociales para buscar información, para consumir productos audiovisuales, para realizar sus compras, para exponer sus ideas o para comunicarse con otros usuarios. Estos millones de mensajes orales y escritos quedan registrados en la web, de modo que el ecosistema digital constituye hoy el mayor corpus de estudio de los distintos usos lingüísticos, por mucho que algunas voces contrarias a este enfoque invaliden la red como corpus al no estar regido por la corrección normativa.

\section{Presentation}

According to data obtained from the 2020 edition of the Cervantes Institute Yearbook (Instituto Cervantes, 2020: 5), nearly 489 million people speak Spanish as their mother tongue, making it the second most spoken language in the world after Mandarin Chinese. In addition to native speakers, if we take into account the worldwide number of speakers, which includes those of limited competence and students of Spanish as a foreign language, then Spanish is the third language in the world just after English and Mandarin Chinese.

These Spanish speakers are present everywhere in the world. In fact, it is estimated that by 2060,27.5\% of the population of the United States will be of Hispanic origin, and the United States will be the second largest Spanish-speaking country after Mexico. For this reason, as we are on the verge of reaching the first quarter mark of the 21st century, the study of Spanish is increasingly taking into account the digital media as a space of mass communication in the Spanish language. In the digital ecosystem, in which it is estimated that around five million queries are made every second (Lewis, 2020), these Spanish speakers go to different websites, mobile phone applications, or different social networks every day in order to find information, use audio-visual products, make purchases, present their ideas, or to communicate with other users. This activity aggregates millions of oral and written messages that are logged on the web, and as a consequence, the digital ecosystem today is the largest study corpus of different language uses, even though some voices that speak out against this approach invalidate the web as a corpus, as it is not governed by normative accuracy.

On the other hand, the large multinational distribution companies (as opposed to the linguistics departments of universities) are the ones who are leading the development of language programmes for natural language processing (conversion of voice to written text and written text to voice; morphosyntactic analysers; de-ambiguators; searches by metadata based on 
Por otro lado, son las grandes empresas multinacionales de distribución (y no los departamentos de lingüística de las universidades) quienes lideran los desarrollos de los programas lingüísticos de procesamiento de lenguaje natural (conversión de voz a texto escrito, y de texto escrito a voz; analizadores morfosintácticos; desambiguadores; búsquedas por metadatos, basadas en una arquitectura léxica que se construye a partir de palabras clave, es decir, a partir del sistema léxico, etc.). Esas empresas, centradas en la atención al cliente, necesitan desarrollar todo ese tipo de herramientas porque la ventana única por la que sus clientes acceden a esos servicios es la lengua: no importa si hablan a sus dispositivos o si teclean palabras en la ventana de un buscador: los contenidos y servicios que se ofrecen desde la web solo son accesibles desde la palabra hablada o escrita. Por ambas razones, con este monográfico, Doxa Comunicación ha puesto el foco en la necesidad de atender el ecosistema digital para estudiar el uso real que de nuestra lengua hacen los hablantes de español, y para analizar la visión de la realidad que ese uso de la lengua pone de manifiesto. Un análisis pormenorizado de esos textos digitales nos permite estudiar, con fiabilidad y a partir de datos objetivos, campos tan dispares y, a su vez, tan complementarios, como los tratados en cada uno de los artículos que constituyen este monográfico: desde el idioma español, su nombre y sus variantes, hasta los cambios que se producen en el léxico o en el discurso; desde el uso que el político o el periodista hacen del idioma, al mensaje que el hablante medio publica en la red; temas diversos que tienen como nexo común la preocupación por nuestra lengua y su estudio y su cuidado.

Sabemos que el idioma español y sus variantes son objeto de análisis y también centro de discusión en las redes, tal y como muestran los artículos de Francisco Carricondo y Amina El-Founti (Universidad de Málaga), y de Gabriel a lexical architecture built from key words, i.e. from the lexical system, etc.) These companies are focused on customer service, and they need to develop all of these types of tools since the only channel through which their customers access these services is the language. It is inconsequential whether they speak to their devices or type words into a search engine-the contents and services offered from the web are only accessible from the spoken or written word.

For both of these reasons, this Doxa Comunicacion monograph focuses on the need to attend to the digital ecosystem in order to study the real use that we Spanish speakers make of our language, and to analyse the vision of the reality that this use of the language reveals. A detailed analysis of these digital texts allows us to reliably study fields as disparate, and likewise as complementary, as those covered in each of the articles that compose this monograph, based on objective data: starting with the Spanish language, its name, and its derivatives, and moving along to the changes occurring in lexicon or discourse; from the use that a politician or a journalist makes of the language to the message that the average speaker posts on the web; diverse topics that have as a common nexus the concern for our language along with its study and preservation.

We know that the Spanish language and its variations are an object of analysis as well as a centre of discussion on the Internet, as shown in the articles by Francisco Carricondo and Amina El-Founti (University of Malaga), in addition to papers by Gabriel Eduardo Alvarado Pávez (City University of New York, USA).

Carriscondo and El-Founti examine the negative perception of the variety of Spanish spoken in Andalusia in their article entitled, "Dos calas en el discurso del odio al andaluz, de la tradición libresca a la prensa digital" (Two explorations of hate speech against the Andalusian variety, from the bookish tradition to the digital press). They rely on three types of documents: book references from the 16th to 19th centuries; audio-visual entries from television series and films; and 
Eduardo Alvarado Pávez (Universidad de la Ciudad de Nueva York, USA).

Carriscondo y El-Founti repasan la percepción negativa de la variedad del español hablado en Andalucía, en su artículo "Dos calas en el discurso del odio al andaluz, desde la tradición libresca hasta la prensa digital". Se basarán en tres tipos de documentos: en referencias librescas de los siglos XVI al XIX; en entradas audiovisuales procedentes de series de televisión y de películas; y en textos periodísticos recogidos de la prensa digital española (es en estos últimos donde los comentarios de los lectores siguen atestiguando, a menudo con virulencia, la vigencia del discurso del odio al andaluz). En sus páginas veremos la necesidad de revisar a fondo y con rigor si tras ese desprestigio del andaluz existen razones lingüísticas o, más bien, sociopolíticas.

Gabriel Eduardo Alvarado, a su vez, se adentrará en el mundo digital para observar cómo, en general, las políticas de lengua española en Chile se consideran hoy poco relevantes, con una escasa presencia de posiciones de orgullo nacional en torno a la forma de hablar español en este país (algo que contrasta con una visión fuertemente positiva de la lengua mapuche). Su trabajo "Ideologías lingüísticas del español en comunidades y páginas de Facebook: políticas de lengua e identidad social en Chile contemporáneo" toma como corpus los discursos sobre el español de Chile en un periodo de diez años (2009-2019), ciñéndose a grupos y páginas con administración chilena en los que se discuten políticas de lengua e identidad en Chile.

También el nombre de la lengua -español/castellano- sigue siendo objeto de discusión en nuestros días. Si Amado Alonso a principios del siglo XX nos legó el gran estudio Castellano, español, idioma nacional. Historia espiritual de tres nombres, y tras él, grandes lingüistas y académicos volvieron sobre esta cuestión, (Coseriu,1987; Alvar, 1991; Salvador, 1992; Mondéjar, 2002 -por citar solo algunos-) hoy, en el ecosistema digital, este asunto vuelve a cobrar journalistic texts collected from the Spanish digital press (the latter is where that readers' comments continue to prove, often with vehemence, the validity of the discourse of hatred toward the Andalusian variety of Spanish). In their pages, we can see the need to make a thorough and rigorous review in order to determine whether or not there are motives behind the discredit of Andalusian Spanish that are linguistic, or even socio-political.

For his part, Gabriel Eduardo Alvarado delves into the digital world in order to observe how Spanish language policies in Chile are generally considered to be of little relevance today, with a scarce presence national pride regarding the way Spanish is spoken in the country (something which contrasts with a strongly positive view of the Mapuche language). His work, which is entitled "Ideologías lingüísticas del español en comunidades y páginas de Facebook: políticas de lengua e identidad social en Chile contemporáneo" (Language ideologies on Spanish in Facebook pages and communities: language and social identity policies in contemporary Chile), is based on a corpus of the discourses on Chilean Spanish over a period of ten years (2009-2019), focusing on groups and pages of text within Chilean administration in which language and identity policies in Chile have been discussed.

The name of the language as well-Spanish or Castilian-is still a subject of discussion today. At the beginning of the 20th century, Amado Alonso bequeathed the great study of Spanish entitled, Castellano, español, idioma nacional. Historia espiritual de tres nombres, and after his contributions, great linguists and academics returned to this issue, (Coseriu,1987; Alvar, 1991; Salvador, 1992; Mondéjar, 2002), to cite just a few. In the digital ecosystem today, this issue has been revived. Florencia Claes (Rey Juan Carlos University), Luis Deltell (Complutense University of Madrid), and María Isabel Hernández Toribio (also of Complutense University of Madrid), address this interesting topic in their article entitled "Español/castellano en Wikipedia: voces y foro de discusión" (Spanish/Castil- 
vida. Florencia Claes (Universidad Rey Juan Carlos), Luis Deltell (Universidad Complutense de Madrid) y M. ${ }^{a}$ Isabel Hernández Toribio (Universidad Complutense de Madrid) abordan este interesante tema en su artículo "Español/castellano en Wikipedia: voces y foro de discusión". En ese texto, los autores analizan dos artículos de la Wikipedia en español: idioma españoly controversia por el nombre del idioma español. A partir del análisis del modo de trabajo colaborativo de la enciclopedia, y a partir también del análisis de los foros de discusión generados en la construcción de estas dos entradas, se describen algunas estrategias de cortesía y descortesía entre usuarios y editores. Sin embargo, quizá lo más significativo de este estudio del funcionamiento interno de la Wikipedia en español sea la constatación de que esta obra no se construye de forma mayoritaria desde ningún estado ni desde ninguna comunidad hablante geográficamente localizada, sino que tiene una fuerte presencia internacional. Además, las dos entradas analizadas no se tratan con un discurso monopolítico sino plural, ya que no hay una autoridad central que articule su construcción. La consecuencia meramente lingüística de este rasgo es la presencia de todas las variedades del español sin preponderancia de ninguna de ellas sobre el resto.

En la era digital en la que estamos viviendo hemos sido testigos de que los teléfonos móviles y las redes sociales como medio de comunicación han ido modelando nuestro lenguaje y, como consecuencia, nuestra manera de dirigirnos al otro.

El discurso cambia, y nuestros políticos -conscientes del enorme poder que ofrece el lenguaje- utilizan los recursos que les ofrece el idioma para llegar a su electorado. Por ello, investigadoras como Carmen González Gómez, Ana Mancera y Paz Villar, o Lucía Ballesteros y Francisco Javier Escobar, se acercarán al análisis discursivo de nuestros gobernantes para estudiarlo desde distintas perspectivas.

julio-diciembre de 2020 ian in Wikipedia: voices and discussion forum). In this text, the authors analyse two articles from the Spanish version of Wikipedia: Idioma español y controversia por el nombre del idioma español (the Spanish language and the controversy over the name of the Spanish language). Based on the analysis of the encyclopaedic, collaborative working method, and also based on the analysis of the discussion forums created in connection with these two entries, some strategies of courtesy and discourtesy between users and editors are described. However, perhaps the most significant aspect of this study of the internal workings of the Spanish version of Wikipedia is the observation that this encyclopaedia is not produced overwhelmingly by a particular state or geographical speaking community, but instead has a strong international presence. Moreover, the two entries analysed are not addressed with a discourse that is monopolistic, but rather pluralistic, as there is no central authority to articulate their development. The purely linguistic consequence of this feature is the presence of all varieties of Spanish without any one of them dominating the others.

In the current digital era, we have witnessed how the use of mobile phones and social networks as a means of communication have been shaping our language and, as a consequence, our way of approaching others.

There has been a change in discourse, and as our politicians are aware of the enormous power offered by language, they use the resources offered by language to reach their electorate. Therefore, researchers such as Carmen González Gómez, Ana Mancera and Paz Villar, as well as Lucía Ballesteros and Francisco Javier Escobar, approach the discursive analysis ofour politicians in order to study language from different perspectives. In her article entitled, "La noción de patria en el discurso de Unidos Podemos (2016-2017): la articulación de un patriotismo constructivo" (The notion of homeland in Unidos Podemos discourse (2016-2017): the articulation of a constructive patriotism), Carmen González Gómez (University of Sala- 
Carmen González Gómez (Universidad de Salamanca) en "La noción de patria en el discurso de Unidos Podemos (2016-2017): la articulación de un patriotismo constructivo" analiza la posición de Podemos en relación con las nociones de patria y nación españolas, y repasa en qué ha consistido la apropiación de esos términos en el discurso de esta formación durante sus dos primeros años de andadura parlamentaria (2016-2017). A partir de ejemplos obtenidos de un corpus constituido por 240 debates parlamentarios, se describe la estrategia de la formación morada para resignificar el concepto de patria y desvincularlo de sus connotaciones conservadoras. Para ello, Unidos Podemos plantea la patria como un contenido histórico que se vincula con los valores de la Segunda República y con la lucha antifascista de los años treinta del siglo XX. Solo en el futuro, con nuevos estudios, se podrá esclarecer si esta apropiación ha instaurado realmente un nuevo marco conceptual o si el patriotismo continúa percibiéndose como patrimonio político de la derecha española.

Ana Mancera Rueda (Universidad de Sevilla) y Paz Villar Hernández (Universidad de Valencia) analizan un corpus de más de 400 titulares sobre el partido político Vox, obtenidos a partir de textos informativos de ocho diarios españoles, durante el periodo previo a las elecciones de abril de 2019. En "Análisis de las estrategias de encuadre discursivo en la cobertura electoral sobre Vox en los titulares de la prensa española” estudian las estrategias de encuadre discursivo, y las autoras concluyen que, si bien la ilocutividad representativa fue mayoritaria en dichos titulares, también son varios los ejemplos en los que, a través de determinadas estrategias léxicas marcadas, se manifiesta con claridad una postura crítica sobre los actos de campaña organizados por Vox y sobre las declaraciones de sus representantes, lo que provocaría preactivaciones contrarias a este partido en la mente del lector. Quedaría abierto el manca) analyses the position of Podemos in relation to the notion of homeland and the Spanish nation, and examines how these terms were appropriated in the discourse of this party during its first two years in Parliament (2016-2017). Based on examples obtained from a corpus of 240 parliamentary debates, this author describes the strategy of Unidos Podemos in changing the concept of homeland and disassociating this idea from the conservative connotations of the word. To this end, Unidos Podemos presents the homeland as a concept with historical meaning associated with the values of the Second Republic and the anti-fascist struggle of the 1930s. Only with continued study will it become clear whether this appropriation has truly established a new conceptual framework, or whether patriotism continues to be perceived as the political heritage of the Spanish right-wing.

Ana Mancera Rueda (University of Sevilla) and Paz Villar Hernández (University of Valencia) have analysed a corpus of more than 400 headlines related to the political party Vox, which were gathered from news reports from eight Spanish newspapers during the period leading up to the April 2019 elections.

In their article entitled, "Análisis de las estrategias de encuadre discursivo en la cobertura electoral sobre Vox en los titulares de la prensa Española" (Analysis of the discursive framing strategies used in Spanish press headlines regarding the electoral coverage of Vox), these two researchers investigate the strategies of discursive framing. They conclude that even though representative illocution took precedence in these headlines, there were various examples in which certain distinct lexical strategies were used that clearly indicate a critical stance on the campaign events organized by Vox along with statements made by its representatives, which would cause pre-activations against this party in the mind of the reader. It is open to debate whether such distinct strategies indicate intentional or unintentional journalistic practices. 
debate de si dichas estrategias marcadas constituyen prácticas periodísticas intencionadas o no.

Por último, Lucía Ballesteros Aguayo y Francisco Javier Escobar Borrego (Universidad de Sevilla) se acercan a la creación neológica que ha partido de nuestros políticos a raíz de la pandemia vivida. En "Ecosistema digital durante la COVID-19: nueva normalidad, desescalada y desconfinamiento", Ballesteros y Escobar estudian cómo, al haber multiplicado la COVID-19 el empleo de las plataformas digitales de las redes sociales, estos espacios digitales se convierten en recursos válidos para el rastreo de determinados usos léxicos, como, por ejemplo, las expresiones nueva normalidad, desescalada y desconfinamiento. Estos términos, cuyo uso ha sido promovido a partir de las disposiciones gubernamentales y se ha visto difundido por las autoridades sanitarias, ponen de manifiesto la necesaria convergencia entre lingüistas, filósofos y comunicadores como el próximo reto que se plantea en el mundo académico.

Nuestra lengua, lo decíamos al principio de estas líneas, la hablan cerca de 500 millones de personas, y millones de mensajes orales y escritos quedan registrados en la web.

Hace tan solo dos años, el 26 de noviembre de 2018, el entonces director de la Real Academia Española, Darío Villanueva, y el Director Honorífico Víctor García de la Concha, presentaban El libro de estilo de la lengua española, libro consensuado por las veintitrés instituciones que forman la Asociación de Academias de la Lengua Española (ASALE) y en el que se incluye un apartado, a cargo del periodista Mario Tascón, referente a la comunicación digital. En dicha presentación nuestros académicos mencionaron cómo las nuevas tecnologías habían cambiado no solo el mundo, sino también la escritura.

Sin duda, la práctica discursiva en el español coloquial en las redes merece un estudio aparte; los indicadores de cortesía, las marcas ortográficas y ortotipográficas, así como
Finally, Lucía Ballesteros Aguayo and Francisco Javier Escobar Borrego (University of Seville) discuss the neological approach that our politicians have taken as a result of the pandemic we have been experiencing. In their article entitled, "Ecosistema digital durante la COVID-19: nueva normalidad, desescalada y desconfinamiento" (The digital ecosystem during the COVID-19 crisis: new normality and lockdown easing and lifting), Ballesteros and Escobar analyse the way in which COVID-19 has multiplied the use of digital platforms on social networks, and as a result these digital spaces have become valid resources for tracking certain lexical use, including expressions such as the new normality, lockdown easing, and lifting. The use of these terms has been promoted by government regulations and disseminated by health authorities, and they highlight the need for consensus among linguists, philosophers, and communicators as the next challenge in the academic world. As we stated at the beginning of this paper, our language is spoken by nearly 500 million people, and millions of spoken and written messages are stored on the Internet.

Merely two years ago, on 26 November 2018, Director Dario Villanueva of La Real Academia Española (Royal Spanish Academy), together with Honorary Director Victor García de la Concha, jointly presented El libro de estilo de la lengua española, (Stylebook of the Spanish language), which is work that was agreed upon by the twenty-three institutions that make up La Asociación de Academias de la Lengua Española (ASALE), and which includes a section on digital communication by journalist Mario Tascón. In the same presentation, our academics mentioned the way in which the new technologies have changed not only the world, but the world of writing as well.

Undoubtedly, discursive practice in colloquial Spanish on social networks deserves a separate analysis; courtesy indicators, orthographic and orthotypographic symbols, as well as discursive markers are the object of interest in linguistic research. 
los marcadores discursivos son objeto de interés en la investigación lingüística.

Raquel Ángel Hidalgo Downing (Universidad Complutense de Madrid), en "Variación de estilo en interacciones digitales: huéspedes y hoteles en reseñas Trip Advisor”, estudia las reseñas realizadas por los huéspedes en Trip Advisor, y sus consiguientes respuestas por parte de las empresas hoteleras. Se estudia así una práctica discursiva concreta en la que reseñas y respuestas se analizan como un todo. Cuatro son los parámetros de estudio: las fórmulas de saludo y despedida, el uso de formas pronominales, los indicadores de cortesía, y las marcas ortográficas y ortotipográficas (este último parámetro lleva a la autora a plantear cuál es el concepto de norma en las redes, unas veces entendido como corrección, y otras, como normalidad). La autora concluye que existe un importante grado de variación de estilo, como consecuencia de que los autores de las reseñas y los autores de las respuestas emplean la plataforma con distinta finalidad comunicativa y con distintos diseños de audiencias.

Por su lado, Ana Pano Alamán (Universidad de Bolonia) aborda el estudio de la presencia y las funciones de los marcadores discursivos en español en tres redes sociales: Facebook, Twitter y el canal de vídeos de YouTube. En "Marcadores discursivos y español coloquial en las redes sociales" ofrece al lector un análisis cuantitativo que confirma que los marcadores más utilizados son los conectores contraargumentativos (pero), aditivos (además, encima, incluso), el comentador pues y algunos conversacionales (claro, hombre, bueno, vamos). Y el análisis cualitativo muestra que son los conectores y marcadores conversacionales o interactivos los que predominan, empleados generalmente para manifestar acuerdo o desacuerdo, y para argumentar la propia opinión. El texto finaliza con una llamada a seguir estudiando en profundidad la influencia de los factores
In her article entitled, "Variación de estilo en interacciones digitales: huéspedes y hoteles en reseñas TripAdvisor" (Style variation in digital interactions: guests and hotels in TripAdvisor reviews), Raquel Ángel Hidalgo Downing (Complutense University of Madrid) studies the reviews written by guests in the Trip Advisor website along with the resulting responses by the hotels. In this way, a specific discursive practice has been examined in which reviews and answers are analysed as a whole. Four study parameters were used in the study: greetings and farewell expressions, the use of pronominal forms, courtesy indicators, and orthographic/orthotypographic symbols (the latter parameter leads the author to ask what is the very concept of rules in the networks, which are sometimes understood as correction, and other times as normality). The author concludes that there is a significant degree of variation in style resulting from the fact that those who write the reviews and those who write the responses use the platform for different communicative purposes, and with different audience profiles.

For her part, Ana Pano Alamán (University of Bologna) has studied the presence and functions of discursive markers in Spanish on three social networks: Facebook, Twitter and YouTube. In "Marcadores discursivos y español coloquial en las redes sociales" (Discursive markers and informal Spanish on social networks), she offers the reader a quantitative analysis that confirms that the most heavily-used markers are counter-argument connectors such as pero (but), those that add information as in además, encima, and incluso (in addition, what's more, and even, the commentator pues, and some that are conversational such as claro, hombre, bueno, vamos (of course, dude, well, come on). Moreover, qualitative analysis shows that conversational or interactive connectors and markers predominate, and are generally used to express agreement or disagreement and to substantiate one's opinion. The text ends with a call for further in-depth study of the in- 
tecnológicos y sociosituacionales de la interacción en los corpus de textos de las redes sociales.

Por último, la investigadora Soledad Carla Chávez Fajardo (Universidad de Chile) en su artículo titulado "Historia del léxico español y la red global: algunos ejemplos” plantea la relevancia de los medios digitales internacionales como corpus de investigación para hacer historia del léxico del español. Con ejemplos concretos de sus investigaciones en lexicología histórica (en los campos de la etimología romance y de la historia del léxico español americano), deja de manifiesto cómo los datos obtenidos en el ecosistema digital complementaron la búsqueda de datos y el cotejo de información requeridos en cualquier investigación léxica que se realice desde una perspectiva histórica y dialectológica.

Es de justicia dejar constancia aquí de que la idea de elaborar este monográfico surgió en el marco del I Congreso Internacional sobre Vulnerabilidad y Cultura Digital, celebrado en Madrid el 18 y 19 de octubre de 2018, y organizado por un consorcio de cinco grupos de investigación consolidados en las universidades madrileñas Universidad CEU San Pablo, Universidad Rey Juan Carlos y Universidad Complutense (CES Villanueva), dentro del marco de la red de investigadores PROVULDIG-CM (S2015/HUM-3434). El Simposio Usos lingüísticos en el ecosistema digital desarrolló cuatro secciones temáticas: el concepto de norma lingüística en la cultura digital; la ciberviolencia o el discurso del odio; los usos sexistas del ciberlenguaje; y el lenguaje como herramienta de manipulación en la red. Del trabajo de todas ellas surgió la idea de desarrollar este monográfico: Realidad y lenguaje en la comunicación digital. La intención es servir de referencia para cualquier investigación que acuda al ecosistema de internet para estudiar el español, tanto en la descripción de nuestro sistema lingüístico como en el estudio de la relación entre lenguaje y realidad.

julio-diciembre de 2020 fluence of technological and socio-situational factors of interaction on corpus materials of social networks.

Finally, in her article entitled, "Historia del léxico español y la red global: algunos ejemplos" (History of Spanish lexicon and the World Wide Web: some cases), researcher Soledad Carla Chávez Fajardo (University of Chile) sets forth the relevance of the international digital media as a corpus for researching the history of Spanish lexicon. With specific examples of her research on historical lexicology (in the fields of Romance etymology and the history of American-Spanish lexicon), she confirms that the data obtained in the digital ecosystem supplements data searches and the comparison of information required in any lexical research carried out from a historical and dialectological perspective.

In all fairness, it must be stated that the idea of preparing this monograph first arose during the I Congreso Internacional sobre Vulnerabilidad y Cultura Digital (1st International Congress on Vulnerability and Digital Culture), held in Madrid on the 18th and 19th of October 2018, and organised by a consortium of five consolidated research groups at the following universities in Madrid: CEU San Pablo, Rey Juan Carlos, and Complutense University of Madrid (CES Villanueva), within the framework of the PROVULDIG-CM research network (S2015/HUM-3434). The symposium entitled, Usos lingüísticos en el ecosistema digital (Linguistic use in the digital ecosystem), developed four thematic sections: Linguistic rules in the digital culture; cyber violence or hate speech; sexist use of cyber-language; and language as a tool of manipulation on the web. As a result of the work involved in all four sections, the idea arose to develop this monograph: Realidad y lenguaje en la comunicación digital (Reality and language in digital communication). The intention was for this to serve as a reference for any research that looks toward the Internet ecosystem to study Spanish, both in the description of our linguistic system and in the study of the relationship between language and reality. 